\title{
Metabolite profiling and antioxidant capacity of lettuce Lactuca sativa var. longifolia grown in an aquaponic system irrigated with shrimp effluents
}

\author{
Perfil de metabolitos y capacidad antioxidante de lechuga Lactuca sativa var. Longifolia \\ en cultivo acuapónico irrigado con efluentes camaronícolas
}

\begin{abstract}
Humberto Ramos-Sotelo', Iza F. Pérez-Ramírez², Marely G. Figueroa-Pérez ${ }^{3}$, Juan F. Fierro-Sañudo ${ }^{4}$, Jesús A. LeónCañedo ${ }^{4}$, Suammy G. Alarcón-Silvas ${ }^{5}$, Cuauhtémoc Reyes-Moreno ${ }^{1}$, Federico Páez-Osuna*6,7

1 Programa Regional de Posgrado en Biotecnología, Universidad Autónoma de Sinaloa, Culiacán, Sinaloa 80030, Mexico.

2 Programa de Posgrado en Alimentos del Centro de la Republica (PROPAC), Centro Universitario, Universidad Autónoma de Querétaro, Mexico.

3 Universidad Tecnológica de Culiacán. Culiacán Sinaloa 80014, Mexico.

4 Posgrado en Ciencias Agropecuarias, Colegio de Ciencias Agropecuarias, Universidad Autónoma de Sinaloa, Culiacán, Sinaloa 80000, Mexico.

5 Posgrado en Ciencias en Recursos Acuáticos, Facultad de Ciencias del Mar, Universidad Autónoma de Sinaloa, Mazatlán, Sinaloa 82017, Mexico.

6 Unidad Académica Mazatlán, Instituto de Ciencias del Mar y Limnología, Universidad Nacional Autónoma de México, Joel Montes Camarena s/n, Playa Sur, Mazatlán, Sinaloa 82040, Mexico.

El Colegio de Sinaloa. Antonio Rosales 435 Pte. Culiacán, Sinaloa, Mexico.
\end{abstract}

\section{ABSTRACT}

This paper focuses on the quality of lettuce var. Iongifolia in an aquaponic culture grown with shrimp effluents from well water (WW, salinity $1.7 \mathrm{~g} \mathrm{~L}^{-1}$ ), diluted seawater (DSW, salinity $1.7 \mathrm{~g} \mathrm{~L}^{-1}$ ), and a hydroponic solution (HS, salinity $1.4 \mathrm{~g}$ $\left.\mathrm{L}^{-1}\right)$ as control. Results evidenced that WW and DSW effluents slightly decreased plants weight, foliage, and yield (5 - 9\%) compared to HS control. Furthermore, WW-lettuce showed higher levels of total phenolic compounds ( 71\%), flavonoids $(\sim 90 \%)$, as well as antioxidant capacity (0.7-3-folds) than HS-plants, mainly in the soluble fraction. WW-lettuce also showed a higher content of total soluble solids ( 16\%) and, a lower saturation of color. WW-lettuce exhibited the highest concentrations of p-hydroxybenzoic, p-coumaric and ferulic acids, as well as quercetin 3-O-glucoside and quercetin 3-O-ramnoside, whereas DSW-lettuce showed the highest levels of caffeic acid, isorhamnetin 3-O-glucoside, kaempferol 3-O-glucoside, kaempferol and quercetin. HSlettuce showed a higher proline content than lettuces from the other treatments. These results indicate that aquaponic lettuce culture with shrimp effluent from WW could be used as an alternative culture system to reduce land area requirements, decrease or eliminate the discharge and impact of shrimp effluents, and simultaneously improve the functional properties of lettuce.

Keywords: Shrimp; Litopenaeus vannamei; Shrimp farming; Aquaponics

\section{RESUMEN}

Este estudio evalúa la calidad de la lechuga var. longifolia en un cultivo acuapónico irrigado con efluentes camaronícolas de agua de pozo (WW, salinidad $1.7 \mathrm{~g} \mathrm{~L}^{-1}$ ), agua de mar diluida (DSW, salinidad $1.7 \mathrm{~g} \mathrm{~L}^{-1}$ ) y una solución hidropónica (HS, salinidad $1.4 \mathrm{~g} \mathrm{~L}^{-1}$ ) como control. Los resultados mostraron que WW y DSW disminuyen ligeramente el peso, follaje y rendimiento (5-9\%) en las plantas comparado con HS. La lechuga-WW mostró un nivel superior de fenólicos totales $(\sim 71 \%)$, flavonoides ( $90 \%)$ y capacidad antioxidante (0.7-3-veces) que las plantas-HS, principalmente en la fracción soluble. La lechuga WW mostró un contenido mayor de sólidos solubles totales ( 16\%) y, menor saturación de color. La lechuga-WW exhibió las concentraciones más altas de ácidos p-hidroxibenzoico, p-cumárico y ferúlico, así como de quercetina 3-O-glucósido y quercetina 3-O-ramnósido. Mientras que la lechuga-DSW mostró las concentraciones más altas de ácido cafeico, isorharmentina 3-O-glucosido, kaempferol 3-O-glucosido, kaempferol y quercetina. La lechuga-HS mostró mayor contenido de prolina. Estos resultados indican que el cultivo aquapónico con efluente camaronícola-WW puede ser usado como una alternativa para reducir los requerimientos de suelo, decrecer o eliminar la descarga e impacto de los efluentes camaronicolas, y simultáneamente mejorar las propiedades funcionales de la lechuga.

Palabras clave: Camarón; Litopenaeus vannamei; Cultivo de camarón; Acuaponia

\section{INTRODUCTION}

There is an increasing interest in the development of new agriculture methods for sustainable food production, given traditional agriculture requires a huge expense of water and land space (Ramos-Sotelo et al., 2019). Besides, shrimp farming also uses a large water amount, due to the constant exchanges for maintain an adequately sustain and quality for shrimp growth. Moreover, shrimp farming produces a 
constant discharge of effluents with high concentrations of organic matter and nutrients that deteriorate the water quality of aquatic ecosystems, in which these effluents are discarded (Páez-Osuna 2001). Therefore, the integration of shrimp farming with agriculture through the irrigation of plants with these effluents could be a sustainable option for food production, as well as for the mitigation of environmental negative effects of both shrimp farming and traditional agriculture (Fierro-Sañudo et al., 2020).

On the other hand, the use of shrimp culture effluents in agriculture represents an alternative source of nutrients for plant cultivation, which allows the reduction of the fertilizer dosage. Furthermore, aquaponics involves plant cultivation without soil by using only water and dissolved nutrients, which have many advantages including faster plant growth, high productivity, easy handling, and greater efficiency in water use. However, there are also disadvantages in terms of the crops, such as adverse effects due to salinity, and an excess or deficiency of nutrients (Fierro-Sañudo et al. 2020). Low-salinity effluents $\left(1-10 \mathrm{~g} \mathrm{~L}^{-1}\right)$ from shrimp farming have available nutrients (Fierro-Sañudo et al., 2020), which make them viable to grow plants, such as lettuce in salinities $<2$ $\mathrm{g} \mathrm{L}^{-1}$ (León-Cañedo et al., 2019). Nonetheless, the critical question is whether such shrimp effluents produce lettuce with a quality comparable to that by traditional hydroponic solutions.

Due to its tolerance to salt stress, the cultivation of lettuce (L. sativa L.) could be integrated with shrimp aquaponic systems. In addition, it has been shown that when plants are exposed to some types of abiotic stress during cultivation, such as salinity or nutrient deficiency, their defense mechanism is activated, which involves an increase in compounds with antioxidant properties which leads to an increase in their nutraceutical properties (Sharma et al., 2019). This has been proved in different varieties of Lactuca sativa $\mathrm{L}$, in which salt stress resulted in an increase of the total phenolic compounds, flavonoids, and in antioxidant activity, improving the quality of the crop at $5.8 \mathrm{~g} \mathrm{~L}^{-1}$ (Ouhibi et al., 2014). Therefore, the variability in the composition and quantity of phytochemicals in lettuce indicate the importance of selecting certain types and characteristics of the water used for irrigation.

In a first study (Ramos-Sotelo et al., 2019), we showed that lettuce L. sativa var. Tropicana M1 grows reasonably well when irrigated with shrimp effluents, and that polyphenols and flavonoid content are even better in the plant produced with well and diluted seawater shrimp effluents. In the present study, the antioxidant properties and production variables of L. sativa var. longifolia were examined, and additionally, metabolite profiling was evaluated. The hypothesis is that the L. sativa var. longifolia lettuce grown with low salinity shrimp effluents exhibits an enhanced quality compared to a commercial hydroponic solution. Therefore, this study evaluated the performance of a hydroponic lettuce culture of the longifolia variety grown with a deep flow technique (DFT) hydroponic system with two low-salinity shrimp effluents (well and diluted seawater, both at $2.7 \mathrm{dS} \mathrm{m}^{-1}$ ). The performance parameters measured were the concentrations of chlorophyll, proteins, lipids, carbohydrates, flavonoids, proline, total and individual phenolic compounds, and antioxidant capacity of the harvested lettuce. The importance of these parameters resides in that they are key indicators to evaluate the nutritional quality of the plants grown with the shrimp effluent in comparison with the HS control.

\section{MATERIALS AND METHODS}

The study was conducted in the YK Experimental

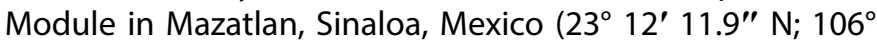
$25^{\prime} 41.29^{\prime \prime}$ W). The aquaponic system consisted of six tanks of $3.14 \mathrm{~m}^{3}$ with two different shrimp cultures both with a salinity of $1.7 \mathrm{~g} \mathrm{~L}^{-1}$, three tanks for each one (Ramos-Sotelo et al., 2019): (i) effluent of shrimp grown in well water (treatment WW) and (ii) effluent of shrimp grown in diluted seawater (treatment DSW). Also, one hydroponic DFT system in triplicate was constructed to grow lettuce using a nutritive solution (HS) as control. Plants of Lactuca sativa L. var. longifolia seedlings were transplanted to their respective treatment 30 days after sowing, and were coupled with tanks of shrimp culture after 50 days of growth. Subsequently, plants were harvested, and both roots and foliage tissues were weighed to estimate production variables. The characterization of shrimp (Litopenaeus vannamei) effluents from both WW and DSW treatments was according to Ramos-Sotelo et al. (2019).

Total soluble solids (TSS), $\mathrm{pH}$, titration acidity (TA), chlorophyll ( $a$ and $b$ ), protein, carbohydrate, and fat contents were quantified according to the AOAC (1997). Color was measured by reflectance in leaves in a portable Minolta CM-2002 spectrophotometer (precision was $9.6 \%$ ). Free proline was evaluated colorimetrically (Bates et al., 1973) (precision $3.9 \%$ ) and results expressed in $\mathrm{mg} \mathrm{g}^{-1}$ dry weight $(d w)$. To extract the soluble fraction compounds (using methanol:water 80:20), and the phenolic compounds from the insoluble fraction (alkaline hydrolysis, ethyl acetate and methanol:water 80:20), samples were processed according to Nguyen and Niemeyer (2008) and Mora-Rochin et al. (2010), respectively. Total phenolic content (TPC) was determined by colorimetric assay, and expressed as gallic acid equivalent $\mathrm{g}^{-1}$ dry sample (GAE/g) (precision $5.1 \%$ ). Total flavonoid content (TFC) was determined by colorimetric assay (Kim et al., 2003), and expressed as $\mathrm{mg}$ of catechin equivalents $\mathrm{g}^{-1}$ dry lettuce (precision $4.9 \%$ ). Antioxidant capacity assay for 2,2'-azinobis(3-ethylbenzothiazoline-6-sulphonic acid) (ABTS) and for 2, 2-Diphenyl-1-picrylhydrazyl (DPPH) assay was quantified as described by Arnao et al. (2001) and Brand-Williams et al. (1995), respectively. Results were expressed in $\mathrm{mg}$ of Trolox equivalents $\mathrm{g}^{-1}$ dry lettuce (precision $5.0 \%$ ). The polyphenol profile was assessed by ultra-performance liquid chromatography coupled to a quadrupole-time of flight, with an atmospheric pressure electrospray ionization interphase (Vion, Waters Co, MA, USA) and a photodiode detector array. The procedure and the mass spectrometry conditions are described in Covarrubias-Cárdenas et al. (2018) (precision 
was $2.2 \%)$.

The data were subjected to the Shapiro-Wilk test, to check the normality. Data were analyzed using the software JMP ver. 10.0.0 (Copyright (c) 2012 SAS Institute Inc.) by non-parametric one-way Kruskal-Wallis test. Comparisons for each pair were made using the Wilcoxon method performed at a significance level of $\mathrm{P}<0.05$, and a $95 \%$ confidence limit to establish the significant difference between the mean parameters for the two treatments (WW and DSW) and the HS control.

\section{RESULTS AND DISCUSION}

In general, both shrimp effluents exhibited similar physicochemical values $(\mathrm{pH} 7.0 \pm 0.3,6.7 \pm 0.2,6.1 \pm 0.0$; temperature $19.3 \pm 1.3,19.6 \pm 2.1,21.6 \pm 1.9^{\circ} \mathrm{C}$; EC 2.6 $\pm 0.3,2.8 \pm$ $0.4,2.3 \pm 0.3 \mathrm{dS} \mathrm{m}^{-1}$; and dissolved oxygen 7.6 $\pm 0.4,7.5 \pm 0.3$, $7.1 \pm 0.1 \mathrm{mg} \mathrm{L}^{-1}$ for WW, DSW and HS control, respectively) and elemental compositions (major ions and nutrients). The concentrations of $\mathrm{Cl}^{-}$in both WW $\left(669 \pm 45 \mathrm{mg} \mathrm{L}^{-1}\right)$ and DSW $\left(620 \pm 34 \mathrm{mg} \mathrm{L}^{-1}\right)$ shrimp effluents were high in comparison to those specified (355 $\mathrm{mg} \mathrm{L}^{-1}$ ) as restriction limits for irrigation (León-Cañedo et al., 2019). At the end of the lettuce crop cycle, the total biomass produced as edible tissue showed a production trend $\mathrm{HS}>\mathrm{WW}>\mathrm{DSW}$ for individual weight, number of leaves and yield (Table 1). These differences could be associated with lower levels of nutrients and high level of $\mathrm{Cl}^{-}$in DSW. Al-Maskri et al. (2010) found similar results in the number of leaves, fresh plant and dry weight of lettuce, with a significant reduction as the salinity increases (2.9 and $5.8 \mathrm{~g} \mathrm{~L}^{-1}$ ), which may be attributed to the osmotic stress and nutritional disorders. However, it is important to ponder that the percentage of decrease was 8-10\%.

The results of the leaves color analysis indicated that lettuce irrigated with DSW and WW effluents showed significant decreases in both parameters ( $L$ and $C$ ) on the CIELAB scale in comparison to the HS control. These changes were higher in the WW treatment (Table 2). The color of the leaves was modified gradually from vivid green, to dull green in plants exposed to both types of effluents (Table 2). This

Table 1. Growth parameters (mean \pm SD) of lettuce cultured with shrimp effluents WW, DSW, and a hydroponic solution (HS).

Tabla 1. Parámetros de crecimiento (promedio \pm SD) de lechuga cultivada con efluente camaronícola WW, DSW, y una solución hidropónica HS.

\begin{tabular}{lccc}
\hline Parameter & WW* & DSW** & HS*** \\
\hline Individual weight (g) & $224.9 \pm 7.9^{\mathrm{b}}$ & $193.8 \pm 9.6^{\mathrm{c}}$ & $234.8 \pm 7.1^{\mathrm{a}}$ \\
\hline Number of leaves & $21.9 \pm 1.4^{\mathrm{b}}$ & $17.8 \pm 1.0^{\mathrm{c}}$ & $23.8 \pm 1.1^{\mathrm{a}}$ \\
\hline Yield (g/plant) & $29.3 \pm 0.9^{\mathrm{b}}$ & $25.2 \pm 0.7^{\mathrm{c}}$ & $31.5 \pm 1.1^{\mathrm{a}}$ \\
\hline \hline
\end{tabular}

Data are mean values $\pm S D,(n=9)$; for the same line (parameter), means with different letters between columns are significantly different $(p<0.05)$. Statistical analyses performed by one-way Kruskal-Wallis test.

* Effluent of shrimp grown in well water (treatment WW).

** Effluent of shrimp grown in diluted seawater (treatment DSW).

***Hydroponic DFT system to grow lettuce using a nutritive solution (HS) as control.
Table 2. Acidity (TA), pH, total soluble solid content (TSS), color L (lightness), $C$ (chroma) and proximate analysis (\% on fresh weight) (mean $\pm S D$ ) of lettuce cultured with shrimp effluents WW, DSW, and the HS control treatment.

Tabla 2. Acidez, pH, sólidos solubles totales (SST), color L, C y análisis proximal (\% en base peso húmedo) (promedio \pm SD) de lechuga cultivada con efluente camaronícola WW, DSW y el control HS.

\begin{tabular}{llll}
\hline & WW* & DSW** & HS*** \\
\hline $\mathrm{pH}$ & $6.05 \pm 0.04^{\mathrm{b}}$ & $6.03 \pm 0.07^{\mathrm{b}}$ & $6.10 \pm 0.04^{\mathrm{a}}$ \\
\hline $\mathrm{TA}$ & $0.12 \pm 0.01^{\mathrm{a}}$ & $0.13 \pm 0.01^{\mathrm{a}}$ & $0.12 \pm 0.02^{\mathrm{a}}$ \\
\hline $\mathrm{TSS}$ & $2.97 \pm 0.53^{\mathrm{a}}$ & $2.21 \pm 0.55^{\mathrm{b}}$ & $2.54 \pm 0.61^{\mathrm{b}}$ \\
\hline $\mathrm{L}$ & $44.23 \pm 5.3^{\mathrm{c}}$ & $41.97 \pm 5.1^{\mathrm{b}}$ & $42.37 \pm 4.3^{\mathrm{a}}$ \\
$\mathrm{C}$ & $28.2 \pm 6.6^{\mathrm{c}}$ & $28.73 \pm 2.8^{\mathrm{b}}$ & $29.18 .3 \pm 4.1^{\mathrm{a}}$ \\
\hline Moisture & $92.16 \pm 2.5^{\mathrm{a}}$ & $90.53 \pm 2.7^{\mathrm{b}}$ & $90.4 \pm 1.4^{\mathrm{b}}$ \\
\hline Fat & $0.41 \pm 0.02^{\mathrm{b}}$ & $0.42 \pm 0.04^{\mathrm{b}}$ & $0.46 \pm 0.05^{\mathrm{a}}$ \\
\hline Ash & $0.85 \pm 0.04^{\mathrm{a}}$ & $0.79 \pm 0.04^{\mathrm{b}}$ & $0.82 \pm 0.06^{\mathrm{a}}$ \\
\hline Protein & $0.95 \pm 0.03^{\mathrm{c}}$ & $1.07 \pm 0.11^{\mathrm{b}}$ & $1.50 \pm 0.06^{\mathrm{a}}$ \\
\hline Carbohydrates & $4.09 \pm 0.66^{\mathrm{c}}$ & $4.51 \pm 0.70^{\mathrm{b}}$ & $5.10 \pm 0.78^{\mathrm{a}}$ \\
\hline
\end{tabular}

Data are mean values $\pm S D,(n=9)$; for the same line, means with different letters between columns are significantly different $(p<0.05)$. Statistical analyses performed by one-way Kruskal-Wallis test.

* Effluent of shrimp grown in well water (treatment WW).

** Effluent of shrimp grown in diluted seawater (treatment DSW).

***Hydroponic DFT system to grow lettuce using a nutritive solution (HS) as control.

may be due to the inhibitory effect of salinity stress over photosynthetic enzymes and the reduced $\mathrm{CO}_{2}$ in the leaves, caused by stomatal closure (DeRidder and Salvucci, 2007). These results are consistent with reports describing the negative effect of salinity on the green color of vegetables (Garrido et al., 2014). TA was similar for both treatments and the $\mathrm{HS}$ control $(P>0.05)$. A small decrease in $\mathrm{pH}$ was observed in lettuces irrigated with DSW and WW effluents. In comparison with the HS control, the TSS was higher in lettuce from WW treatments (Table 2). These results agree with those obtained by Magdi et al. (2013) for bean plants.

Proximal analysis on the harvested lettuce revealed a general trend HS $>$ DSW $>$ WW for fat, protein, and carbohydrates (Table 2). It has been shown that protein content significantly decreased in plants treated with sodium chloride at low concentrations (Ayala-Astorga and Alcaraz-Melémdez, 2010). One effect of saline stress in plants is the loss of potassium ions through roots, which causes a physiological imbalance, given potassium is essential for protein synthesis. Furthermore, this also affects plant growth and development, and if the stress is prolonged, it could affect protein synthesis and eventually diminish its concentrations (Chen et al., 2007). Carbohydrates were reduced $\sim 20$ and $\sim 12 \%$ in lettuces from WW and DSW treatments, respectively, in comparison to the HS control (Table 2). Such results are consistent with those obtained by Magdi et al. (2013), who reported that organic acids, especially sugars, are the main solutes involved in the osmotic adjustment of some plants growing under osmotic and saline stress. Similarly, lipid content decreased in lettuces harvested with WW and DSW treatments in comparison with 
the HS control (Table 2). Under salt stress conditions, important changes in lipids metabolism occur in plants, mainly the degradation of the plasmatic membrane due to a reduction in the desaturase activity. Some plants react against the oxidative stress induced by salinity by restructuring membranes and reducing polyunsaturated fatty acid content, which affects the membrane fluidity and restricts the permeability of $\mathrm{Na}^{+}$and $\mathrm{Cl}^{-}$ions (Mehraban et al., 2017).

Figure 1 shows that the total phenolic content increased around 14 and 70\% for DSW and WW treatments, respectively, compared to the HS control in the soluble fraction. However, for the insoluble fraction, the content of phenolic compounds was higher in the control plants. Regarding flavonoid content, WW treatment evidenced increases by 2 -fold in comparison with the HS control. Conversely, DSW showed no significant differences with the HS control. Calcium deficiency during plant cultivation can induce an increase of secondary metabolites, mainly phenolic compounds (Chishaki and Horiguchi, 1997). It has also been shown that the application of $\mathrm{CaCl}_{2}$ can lead to an improvement in the retention of phenolic compounds, and the antioxidant capacity for the first seven days in lettuce (Materska et al., 2019). In our previous study (Ramos-Sotelo et al., 2019), it was evidenced that Mg levels in WW (57.5 $\left.\mathrm{mg} \mathrm{L}^{-1}\right)$ effluents were significantly higher than in DSW (43.7 $\left.\mathrm{mg} \mathrm{L}^{-1}\right)$. It is known that high $\mathrm{Mg}^{+2}$ levels affect the absorption of $\mathrm{Ca}^{+2}$ by plants, which could lead to the aforementioned increase of phenolic compounds in WW treatments (Ramos-Sotelo et al., 2019).

Furthermore, results indicated that chlorophyll a and b levels were slightly reduced $(\sim 7 \%)$ by WW treatment. This effect is related to the results observed in color parameters for the WW treatment, since chlorophyll is the most important pigment in green vegetables. Reduction in chlorophyll occurs in salt-stressed plants, due to the inhibitory effect on the biosynthesis of the different chlorophyll fractions by the accumulation of major ions. Ion imbalance affects the forces that stabilize the pigment protein liquid complex, in chloroplasts (Acosta-Motos et al., 2017).

The results of this study indicated a reduction of 25 to $44 \%$ in the proline content of plants irrigated with DSW and WW effluents, respectively, compared with the HS control. Shetty (2004) proposed a link between the proline accumulation and the energy transfer to the phenylpropanoids biosynthesis, through the pentose phosphate pathway. Proline synthesis involves the oxidation of NADPH, which feeds the pentose phosphate pathway, providing precursors for phenolic biosynthesis through the shikimic acid pathway. This could explain the proline decrease in plants grown with WW and DSW effluents. Sharma and Ramawat (2013) found increases of up to $40 \%$ in proline content of Salvadora persica calluses when applying $50 \mathrm{mM} \mathrm{NaCl}$. However, when $200 \mathrm{mM}$ $\mathrm{NaCl}$ were applied in this same study, proline decreased considerably. Conversely, this last treatment with the lowest proline content showed the highest antioxidant capacity, which suggests that this decrease is related to its use as a precursor in the synthesis of compounds with antioxidant potential.

Table 3 shows the specific phenolic compounds, whose concentration was modified in lettuce by the irrigation with shrimp effluents. Sixteen compounds were identified in the soluble fraction and ten in the insoluble fraction. Significantly higher levels of isorhamnetin 3-O-glucoside, quercetin 3-O-glucoside, quercetin 3-O-rhamnoside, dihydroxybenzoic
A
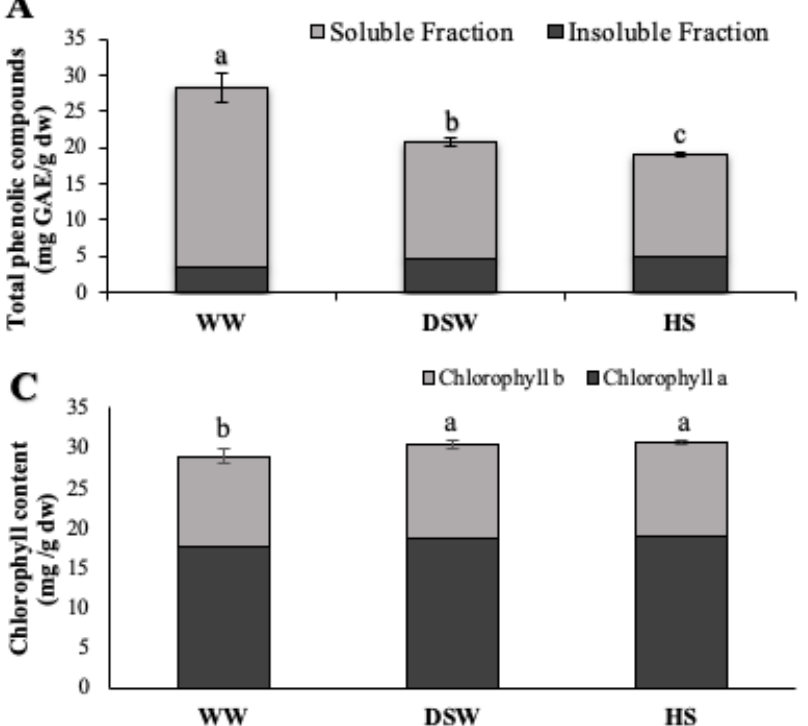

B

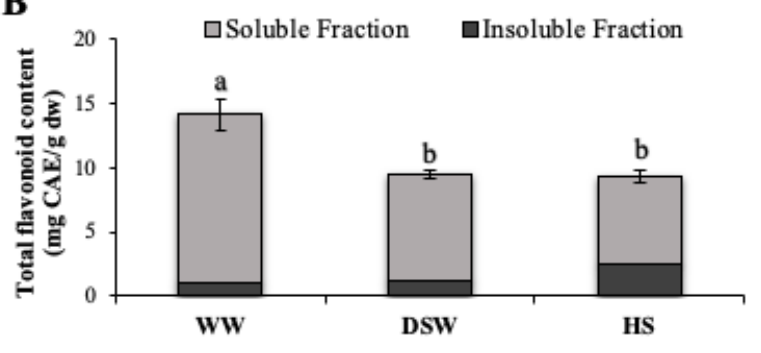

D

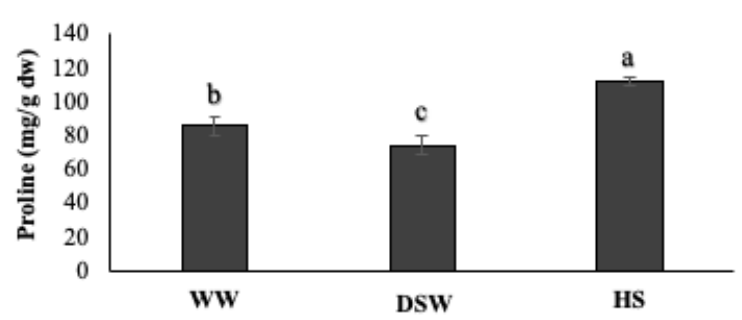

Figure 1. A, Total phenolic; B, flavonoid; $C$, chlorophyll a and b; and D, proline contents (mean $\pm S D$ ) of lettuce cultured with shrimp effluents from WW, DSW, and the control treatment (HS). Treatments with different letters $(a, b, c)$ indicate significant differences ( $p<0.05)$. Statistical analyses performed by a one-way Kruskal-Wallis test.

Figura 1. A, Fenólicos totales; B, flavonoides; C, clorofila a y b; y D, contenido de prolina (promedio \pm SD) de lechuga cultivada con effluentes camaronícolas WW, DSW y el control (HS). Tratamientos con diferente letra $(a, b, c)$ indica diferencias significativas ( $p<0.05)$. Análisis estadístico efectuado con una prueba de Kruskal-Wallis. 
Table 3. Metabolite profiling of soluble and insoluble fractions (mean \pm SD) of lettuce cultured with shrimp effluents from WW, DSW, and the HS control treatment. Tabla 3. Perfil de metobolitos de las fracciones soluble e insoluble (promedio \pm SD) de lechuga cultivada con efluentes camaronícolas WW, DSW y el control HS.

\begin{tabular}{|c|c|c|c|c|c|c|c|c|}
\hline \multirow{3}{*}{ RT (min) } & \multirow{3}{*}{ Compound } & \multirow{3}{*}{$\begin{array}{l}\text { Mass } \\
(\mathrm{m} / \mathbf{z})\end{array}$} & \multicolumn{6}{|c|}{ Concentration $\left(\mu \mathrm{g} \mathrm{mg}^{-1}\right)$} \\
\hline & & & \multicolumn{3}{|c|}{ Soluble fraction } & \multicolumn{3}{|c|}{ Insoluble fraction } \\
\hline & & & WW & DSW & HS & WW & DSW & HS \\
\hline 1.79 & $\begin{array}{l}\text { 4-O-glucoside of dihydroxybenzoic acid } \\
\text { isomer I }\end{array}$ & 315.07 & - & - & - & - & $0.02 \pm 0.00^{\mathrm{a}}$ & $0.02 \pm 0.00^{\mathrm{a}}$ \\
\hline 1.81 & Dihydroxybenzoic acid glucoside isomer I & 315.07 & $0.52 \pm 0.48^{\mathrm{a}}$ & $1.08 \pm 0.47^{\mathrm{a}}$ & $1.07 \pm 0.32^{\mathrm{a}}$ & - & - & - \\
\hline 1.9 & Dihydroxybenzoic acid glucoside isomer II & 315.07 & $0.83 \pm 0.15^{\mathrm{a}}$ & $1.28 \pm 0.37^{\mathrm{a}}$ & $0.81 \pm 0.14^{\mathrm{a}}$ & $0.01^{\mathrm{a}}$ & - & - \\
\hline 2.07 & Dihydroxybenzoic acid glucoside isomer III & 315.07 & $0.32 \pm 0.03^{\mathrm{a}}$ & $0.28 \pm 0.03^{\mathrm{a}}$ & - & - & - & - \\
\hline 2.12 & Caffeic acid 4-O-glucoside & 341.09 & $0.34 \pm 0.10^{\mathrm{a}}$ & $0.46 \pm 0.01^{\mathrm{a}}$ & $0.40 \pm 0.04^{\mathrm{a}}$ & $0.23 \pm 0.02^{b}$ & $0.35 \pm 0.00^{\mathrm{a}}$ & $0.01 \pm 0.00^{c}$ \\
\hline 2.38 & P-Hydroxybenzoic acid* & 137.02 & $1.9 \pm 1.42^{\mathrm{a}}$ & $3.25 \pm 0.36^{\mathrm{a}}$ & $2.75 \pm 0.48^{\mathrm{a}}$ & - & - & - \\
\hline 2.49 & Isomeric dihydrobenzoic acid II & 153.02 & - & $2.09 \pm 0.13^{\mathrm{a}}$ & $0.44 \pm 0.08^{b}$ & - & - & - \\
\hline 2.55 & Isomeric caffeoylquinic acid I & 353.09 & - & - & - & $3.75 \pm 0.02^{\mathrm{a}}$ & $0.45 \pm 0.01^{b}$ & $0.02 \pm 0.01^{c}$ \\
\hline 2.8 & Caffeic acid * & 179.04 & $18.09 \pm 5.18^{c}$ & $60.16 \pm 5.82^{\mathrm{a}}$ & $43.96 \pm 5.04^{b}$ & - & - & - \\
\hline 2.97 & Benzoic acid & 121.03 & $0.26 \pm 0.01^{b}$ & $0.33 \pm 0.04^{\mathrm{ab}}$ & $0.36 \pm 0.06^{\mathrm{a}}$ & - & - & - \\
\hline 3.01 & p-Coumaroylquinic acid isomer I & 337.09 & - & - & - & $0.12 \pm 0.00^{\mathrm{a}}$ & $0.01 \pm 0.00^{b}$ & - \\
\hline 3.44 & P-Coumaric acid * & 163.04 & $3.82 \pm 0.37^{\mathrm{a}}$ & $3.49 \pm 0.43^{\mathrm{a}}$ & $2.43 \pm 0.28^{b}$ & - & - & - \\
\hline 3.91 & Ferulic acid * & 193.05 & $0.41 \pm 0.07^{\mathrm{a}}$ & $0.31 \pm 0.04^{\mathrm{a}}$ & - & - & - & - \\
\hline 4.15 & Isoramnetine 3-O-glucoside & 477.07 & $3.26 \pm 0.60^{b}$ & $5.95 \pm 0.93^{\mathrm{a}}$ & $1.12 \pm 0.16^{c}$ & $3.54 \pm 0.15^{\mathrm{a}}$ & $0.55 \pm 0.00^{b}$ & - \\
\hline 4.24 & Quercetin 3-O-glucoside & 463.09 & $17.64 \pm 3.15^{\mathrm{a}}$ & $13.81 \pm 2.66^{b}$ & $4.19 \pm 0.80^{c}$ & $4.64 \pm 0.20^{\mathrm{a}}$ & $1.37 \pm 0.02^{b}$ & $0.04 \pm 0.00^{c}$ \\
\hline 4.4 & Kaempferol 3-O-glucoside & 447.09 & $0.63 \pm 0.08^{\mathrm{a}}$ & $0.83 \pm 0.12^{\mathrm{a}}$ & $0.70 \pm 0.12^{\mathrm{a}}$ & $0.01 \pm 0.00^{\mathrm{a}}$ & - & - \\
\hline 5.1 & Dicaffeoylquinic acid isomer I & 515.12 & - & - & - & $3.23 \pm 0.05^{\mathrm{a}}$ & $0.08 \pm 0.00^{b}$ & $0.01 \pm 0.00^{c}$ \\
\hline 5.17 & Quercetin 3-O-ramnoside & 447.09 & $0.57 \pm 0.04^{\mathrm{a}}$ & $0.43 \pm 0.13^{\mathrm{a}}$ & $0.18 \pm 0.04^{b}$ & - & - & - \\
\hline 6.14 & Isomeric Dicafeoilquinico Acid II & 515.12 & - & - & - & $0.03 \pm 0.00^{\mathrm{a}}$ & $0.01 \pm 0.00^{\mathrm{a}}$ & - \\
\hline 8.73 & Quercetin* & 301.03 & $0.37 \pm 0.07^{b}$ & $0.77 \pm 0.13^{a}$ & $0.39 \pm 0.05^{b}$ & - & - & - \\
\hline 8.85 & Kaempferol * & 285.04 & $0.54 \pm 0.12^{\mathrm{b}}$ & $1.60 \pm 0.52^{\mathrm{a}}$ & $0.70 \pm 0.09^{b}$ & - & - & - \\
\hline
\end{tabular}

Data are mean values $\pm S D,(n=9)$; treatments with different letters $(a, b, c)$ indicate significant differences $(p<0.05)$ Statistical analyses performed by one-way Kruskal-Wallis test. *: Confirmed with commercial standards. -: not detected $\left(<0.01 \mu \mathrm{g} \mathrm{mg}^{-1}\right)$. Relative quantification was performed in comparison with naringenin (flavanones), kaempferol (flavonols), p-hydroxybenzoic acid (hydroxybenzoic acids), and caffeic acid (hydroxycinnamic acids).

WW: Effluent of shrimp grown in well water; DSW: Effluent of shrimp grown in diluted seawater; HS: Hydroponic DFT system to grow lettuce using a nutritive solution as control.

acid, p-Coumaric acid and ferulic acid were found in the soluble fraction of plants irrigated with WW and DSW effluents compared to the HS control. Most of these compounds showed the highest increases with the DSW treatment. Ribas-Agusti et al. (2011) found similar profiles to the ones in this study identifying eleven individual compounds, mainly esters of caffeic and coumaric acid, as well as quercetin glycosides. Isorhamnetin and quercetin glucosides increased by 5 and 3-fold in DSW treatments compared to the HS control; these flavonols have demonstrated important health benefit properties. Furthermore, it has been shown that isorhamnetin exerts anticancer effects by reducing tumor growth and COX-2 expression (Kim et al., 2011). On the other hand, quercetin glucosides have shown positive health effects including activities such as anticancer, antitumor, cardiovascular protection, antiulcer, antiviral, antiallergy, antiinflammatory, antidiabetic, gastroprotective effects, antihypertensive, immunomodulatory, and antioxidant (Anand David et al., 2016).
Phenolic acids, mainly caffeic, $\mathrm{p}$-coumaric and ferulic identified in the soluble fraction, also evidenced an increase of about $40 \%$ in lettuces irrigated with DSW effluents compared to the control plants. These compounds are of great importance in human health given their protective antioxidant behavior and biological activities, such as the selective blockage of leukotrienes biosynthesis, which are involved in immunoregulation diseases, such as asthma and allergic reactions. Other studies have reported that caffeic acid and some of its esters might possess antitumor activity against colon carcinogenesis (Robbins, 2003). Regarding the insoluble fraction, significant increases were recorded in glucosides of caffeic acid. Similar to the soluble fraction, the highest increases were found in isorhamnetin and quercetin glucosides. Therefore, changes in phenolic profile of lettuce irrigated with DSW shrimp effluents could be of great importance in the nutraceutical quality of the products obtained. 
Figure 2 shows the capacity of soluble and insoluble lettuce fractions to inhibit the formation of ABTS and DPPH radicals. Results indicated that the soluble fraction of plants irrigated with DSW shrimp effluents, increased the antioxidant capacity by $61 \%$ by the ABTS method as compared to control samples. However, the greatest effect for this radical inhibition was exerted by samples of WW treatment, which improved their antioxidant capacity up by $\sim 3$-fold in comparison to the HS control. It is known that the ABTS radical is scavenged with a wide range of compounds, mainly phenolic acids and flavonoids (Lin et al., 2016). These results positively correlate with those obtained for total phenolic and flavonoid contents. Moreover, lettuce irrigated with WW effluents showed significantly higher amounts of $p$-coumaric and ferulic acids, as well as glucosides of isorhamnetin and quercetin (Table 3). On the other hand, the ABTS antioxidant capacity of insoluble fraction was about 5 times lower than for the soluble fraction, which could be attributed to the lower amount of phenolic acids and flavonoids found in these samples (Table 3).

With respect to the inhibition of the DPPH radical (Fig. $2 B$ ), we found increases of $42 \%$ in the antioxidant capacity of lettuce from WW treatments as compared to the HS control
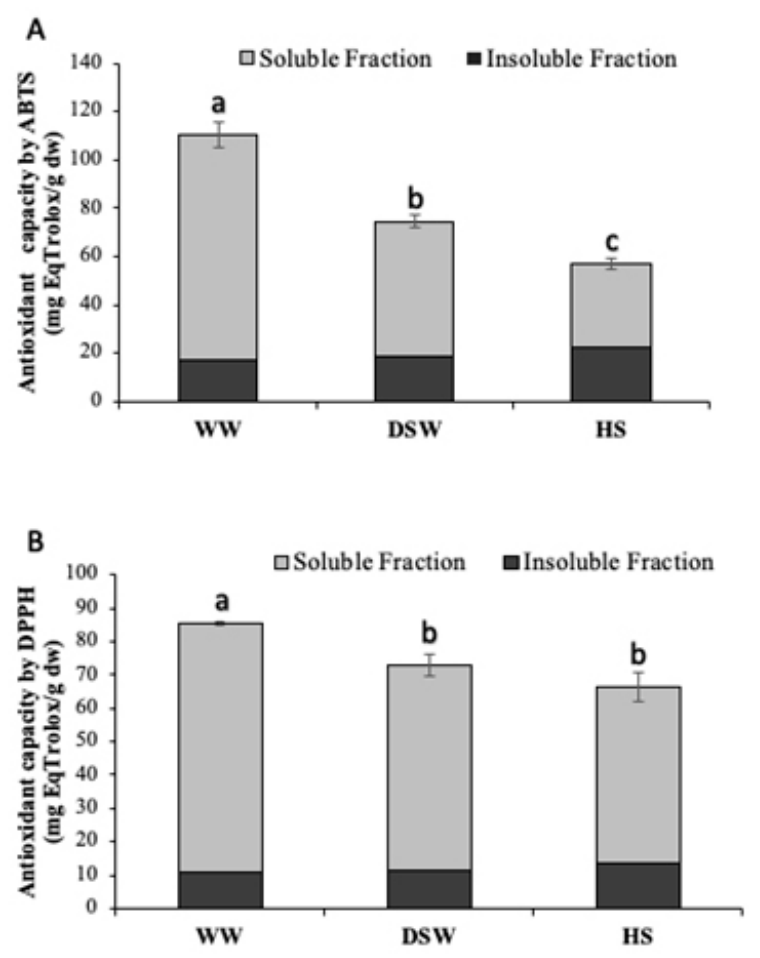

Figure 2. Antioxidant capacity ABTS (A) and DPPH (B) (mean \pm SD) of soluble and insoluble fractions of lettuce cultured with shrimp effluents from WW, DSW, and the HS control. Treatments with different letters $(a, b, c)$ indicate significant differences $(p<0.05)$. Statistical analyses performed by a one-way Kruskal-Wallis test.

Figura 2. Capacidad antioxidante ABTS (A) y DPPH (B) (promedio \pm SD) de las fracciones soluble e insoluble de lechuga cultivada con efluentes camaronícolas WW, DSW y el control HS. Tratamientos con diferente letra $(a, b, c)$ indica diferencias significativas $(p<0.05)$. Análisis estadístico efectuado con una prueba de Kruskal-Wallis. in soluble fraction. It is known that the DPPH radical is highly inhibited by flavonoids, but not by phenolic acids or sugars (Mareček et al., 2017), also, that DPPH is a electron transfer method and flavonoids are able to chelate free radicals immediately by donating hydrogen atom or by single-electron transfer (Banjarnahor and Artani, 2015). Ratty et al. (1988) tested flavonoid-DPPH interaction showing that quercetin was the most potent and it inhibited $42 \%$, while the other flavonoids inhibited $14-23 \%$, which agrees with the 4 -fold increase found in quercetin 3-O-glucoside levels (Table 3) observed for the soluble fraction of the WW treatment. This compound has been identified as an excellent inhibitor of DPPH formation, as well as a potent alleviator of cytotoxicity on rat hepatocytes by improving the antioxidant activity of cells (Hu et al., 2014). Regarding the insoluble fraction, DPPH inhibition was seven times lower than the observed for soluble fraction. This could be related to the small amount of phenolic acids and flavonoids identified in this fraction, indicating that the main antioxidant compounds in lettuce corresponds to soluble phenolics.

\section{CONCLUSIONS}

Shrimp effluent from low-salinity cultures has the potential to be used as an alternative source of water and nutrients for hydroponic lettuce var. longifolia cultivation, since it does not significantly affect the yield, physicochemical, or nutritional parameters of plants. The saline stress produced by the irrigation with WW effluents slightly decreased chlorophyll content in lettuce, and therefore its green color. Lettuce harvested from WW and DSW shrimp effluent treatments evidenced an improved quality in terms of phenolic compounds profile, mainly in plants irrigated with WW effluents, which highly increased its phenolic acid and flavanol contents, as well as its antioxidant capacity, by ABTS and DPPH methods. Thus, these plants could exert enhanced health benefits. These conclusions confirm the hypothesis that the lettuce $L$. sativa var. longifolia grown with low salinity shrimp effluents, exhibits an enhanced quality compared to that grown with a hydroponic solution.

\section{ACKNOWLEDGEMENTS}

Study supported by Instituto de Ciencias del Mar y Limnología, Universidad Nacional Autónoma de México and Facultad de Ciencias Químico-Biológicas, Universidad Autónoma de Sinaloa. We thank to H. Bojórquez-Leyva for the help in the lab.

\section{REFERENCES}

Acosta-Motos, J.R., Ortuño, M.F., Bernal-Vicente, A., DiazVivancos, P., Sanchez-Blanco, M.J. and Hernandez, J.A. 2017. Plant responses to salt stress: adaptive mechanisms. Agronomy 7(1):1-38.

Al-Maskri, A., Al Kharusi, L., Al-Miqbali, H. and Khan, M. 2010. Effects of salinity stress on growth of lettuce (Lactuca sativa) under closed-recycle nutrient film technique. International Journal of Agriculture and Biology 12(3):377-380. 
Anand David, A.V., Arulmoli, R. and Parasuraman, S. 2016. Overviews of biological importance of quercetin: a bioactive flavonoid. Pharmacological Reviews 10(20):84-89.

AOAC. 1997. Official Methods of Analysis. Association of Official Analytical Chemists, Washington, D.C.

Arnao, M.B., Cano, A., Alcolea, J.F. and Acosta, M. 2001. Estimation of free radical-quenching activity of leaf pigment extracts. Phytochemical Analysis 12(2):138-143.

Ayala-Astorga, G.I. and Alcaraz-Meléndez, L. 2010. Salinity effects on protein content, lipid peroxidation, pigments, and proline in Paulownia imperialis (Siebold \&amp; Zuccarini) and Paulownia fortunei (Seemann \&amp; Hemsley) grown in vitro. Electronic Journal of Biotechnology 13(5):13-14.

Banjarnahor, S.D.S. and Artanti, N. 2015. Antioxidant properties of flavonoids. Medical Journal of Indonesia. 23(4):239-244.

Bates, L.S., Waldren, R.P. and Teare, I.D. 1973. Rapid determination of free proline for water-stress studies. Plant and Soil 39(1):205-207.

Brand-Williams, W., Cuvelier, M.E. and Berset, C. 1995. Use of a free radical method to evaluate antioxidant activity. LWTFood Science and Technology 28(1):25-30.

Chen, Z., Cuin, T.A., Zhou, M., Twomey, A., Naidu, B.P. and Shabala, S. 2007. Compatible solute accumulation and stressmitigating effects in barley genotypes contrasting in their salt tolerance. Journal of Experimental Botany 58(15-16): 4245-4255.

Chishaki, N. and Horiguchi, T. 1997. Responses of secondary metabolism in plants to nutrient deficiency. Soil Science and Plant Nutrition 43:987-991.

Covarrubias-Cárdenas, A., Martínez-Castillo, J., Medina-Torres, N., Ayora-Talavera, T., Espinosa-Andrews, H., García-Cruz, N. and Pacheco, N. 2018. Antioxidant capacity and UPLC-PDA ESI-MS phenolic profile of stevia rebaudiana dry powder extracts obtained by ultrasound assisted extraction. Agronomy 8(9):170.

DeRidder BP, Salvucci M. 2007. Modulation of Rubisco activase gene expression during heat stress in cotton (Gossypium hirsutum L.) involves post-transcriptional mechanisms. Plant Sci. 172(2):246-252.

Fierro-Sañudo, J.F., Rodriguez-Montes de Oca, G. and PáezOsuna F. 2020. Co-culture of shrimp with commercial plants: a review. Reviews in Aquaculture 12:2411-2428.

Garrido, Y., Tudela, J.A., Marin, A., Mestre, T., Martinez, V. and Gil, M.I. 2014. Physiological, phytochemical and structural changes of multi-leaf lettuce caused by salt stress. Journal of the Science of Food and Agriculture 94(8):1592-1599.

Hu, L., Yu, W., Li, Y., Prasad, K. and Tang, Z. 2014. Antioxidant activity of extract and its major constituents from okra seed on rat hepatocytes injured by carbon tetrachloride. BioMed Research International 341291.

Kim, D.O., Chun, O.K., Kim, Y.J., Moon, H.Y. and Lee, C.Y. 2003. Quantification of polyphenolics and their antioxidant capacity in fresh plums. Journal of Agricultural and Food Chemistry 51(22):6509-6515.

Kim, J.E., Lee, D.E., Lee, K.W., Son, J.E., Seo, S.K., Li, J., Jung, S.K., Heo, Y.S., Mottamal, M., Bode, A.M., Dong, Z. and Lee, H.J. 2011. Isorhamnetin suppresses skin cancer through direct inhibition of MEK1 and PI3-K. Cancer Prevention Research 4(4):582-591.
León-Cañedo, J.A., Alarcón-Silvas, S.G., Fierro-Sanudo, J.F., Rodríguez-Montes de Oca, G.A., Partida-Ruvalcaba, L., Díaz-Valdés, T. and Páez-Osuna, F. 2019. Mercury and other trace metals in lettuce (Lactuca sativa) grown with two lowsalinity shrimp effluents: accumulation and human health risk assessment. Science of the Total Environment 650:25352544.

Lin, D., Xiao, M., Zhao, J., Li, Z., Xing, B., Li, X., Kong, M., Li, L., Zhang, Q., Liu, Y., Chen, H., Qin, W., Wu, H. and Chen, S. 2016. An overview of plant phenolic compounds and their importance in human nutrition and management of type 2 diabetes. Molecules 21(10):1374.

Magdi, T.A., Mervat, S.S., URS, S. and Abdel-Kareem, M.E.S. 2013. Interactive effects of salinity stress and nicotinamide on physiological and biochemical parameters of faba bean plant. Acta Biológica Colombiana 18:499-510.

Mareček, V., Mikyška, A., Hampel, D., Čejka, P., Neuwirthová, J., Malachová, A. and Cerkal, R. 2017. ABTS and DPPH methods as a tool for studying antioxidant capacity of spring barley and malt. Journal of Cereal Sciences 73:40-45.

Materska, M., Olszówka, K., Chilczuk, B., Stochmal, A., Pecio, T., Pacholczyk-Sienicka, B., Piacente, S., Pizza, C. and Masullo, M. 2019. Polyphenolic profiles in lettuce (Lactuca sativa L.) after $\mathrm{CaCl}_{2}$ treatment and cold storage. European Food Research and Technology 245: 733-744.

Mehraban, A., Kadali, F., and Miri, M. 2017. Influence of salt stress on lipids metabolism, photorespiration, photosynthesis and chlorophyll fluorescence in crop plants. Chemistry Research Journal 2(3):127-132.

Mora-Rochin, S., Gutiérrez-Uribe, J.A., Serna-Saldivar, S.O., Sánchez-Peña, P., Reyes-Moreno, C. and Milán-Carrillo, J. 2010. Phenolic content and antioxidant activity of tortillas produced from pigmented maize processed by conventional nixtamalization or extrusion cooking. Journal of Cereal Science 52(3): 502-508.

Nguyen P.M., Niemeyer E.D. Effects of nitrogen fertilization on the phenolic composition and antioxidant properties of basil (Ocimum basilicum L.) Journal of Agricultural and Food Chemistry. 2008;56(18):8685-8691.

Ouhibi C, Attia H, Rebah F, Msilini N, Chebbi M, Aarrouf J, Urban L, Lachaal M. 2014. Salt stress mitigation by seed priming with UV-C in lettuce plants: growth, antioxidant activity and phenolic compounds. Plant Physiol Biochem. 83:126-33.

Páez-Osuna, F. 2001. The environmental impact of shrimp aquaculture: causes, effects, and mitigating alternatives. Environmental Management 28(1):131-140.

Ramos-Sotelo, H., Valdez-Ortiz, Á., Germán-Báez, L.J., FierroSañudo, J.F., León-Cañedo, J.A., Alarcón-Silvas, S.G., ReyesMoreno, C. and Páez-Osuna, F. 2019. Quality of lettuce Lactuca sativa (var. Tropicana M1) grown with two lowsalinity shrimp effluents. Food Chemistry: X 2:100027.

Ratty, A. K., Sunamoto, J, j. and Das, N.P. 1998. Interaction of flavonoids with 1,1-diphenyl-2-picrylhydrazyl free radical, liposomal membranes and soybean lipoxygenase-1. Biochemical pharmacology 37(6):989-995.

Ribas-Agusti, A., Gratacos-Cubarsi, M., Sarraga, C., GarciaRegueiro, J.A. and Castellari, M. 2011. Analysis of eleven phenolic compounds including novel p-coumaroyl derivatives in lettuce (Lactuca sativa L.) by ultra-highperformance liquid chromatography with photodiode array and mass spectrometry detection. Phytochemical Analysis 22(6):555-563. 
Robbins, R.J. 2003. Phenolic acids in foods: an overview of analytical methodology. Journal of Agricultural and Food Chemitry 51(10):2866-2887.

Sharma, V. and Ramawat, K.G. 2013. Salinity-induced modulation of growth and antioxidant activity in the callus cultures of miswak (Salvadora persica). 3 Biotech 3(1): 11-17.
Sharma, A., Shahzad, B., Rehman, A., Bhardwaj, R., Landi, M. and Zheng, B. 2019. Response of phenylpropanoid pathway and the role of polyphenols in plants under abiotic stress. Molecules 24(13):2452.

Shetty, K. 2004. Role of proline-linked pentose phosphate pathway in biosynthesis of plant phenolics for functional food and environmental applications: a review. Process Biochemistry 39(7):789-804. 